\title{
Phytosociology and cover analysis in the suppression of weeds from an Amazonian agrosystem
}

\author{
Lais Alves da Gama ${ }^{1} \oplus$, Bruna Nogueira Leite ${ }^{2} \oplus$, Sara Cruz Pinheiro ${ }^{2} \oplus$, Marcelo Ferreira Reis ${ }^{2} \oplus$,

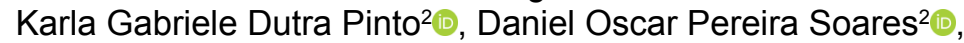 \\ Firmino José do Nascimento Filho ${ }^{[}$, Sônia Maria Figueiredo Albertino ${ }^{[}$

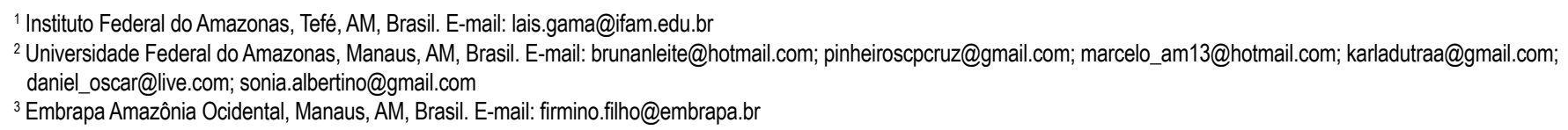

ABSTRACT: Weeds can occur in cultivated areas, competing with crops and causing considerable losses. Herbicides are the basis of weed control; however, they are questionable due to their possible negative impacts on human health and the environment. An alternative for controlling weeds is using cover plants. This study aimed to determine the floristic composition of weeds in an Amazonian agrosystem with cover plants and to evaluate the production of biomass, the soil cover rate and the weed suppression potential of cover plants. The experimental design was in randomized blocks, in a $4 \times 2$ factorial scheme. The factors under study were the cover species (Brachiaria ruziziensis, Canavalia ensiformis, Mucuna deeringiana) and the control group that consisted of weeds, evaluated during two agricultural years (2017 and 2018), with four replicates. Digitaria horizontalis was the most important weed species and was completely suppressed by $B$. ruziziensis. This cover type had a large production of biomass, greater coverage of the soil and high suppression of weeds in the Amazonian agrosystem.

Key words: competition; control; phytomass

\section{Fitossociologia e análise de coberturas na supressão das plantas daninhas de um agrossistema amazônico}

RESUMO: As plantas daninhas podem ocorrer nas áreas cultivadas causando perdas consideráveis aos cultivos. Os herbicidas são a base do controle de plantas daninhas, entretanto, seu uso é questionável devido aos seus possíveis impactos negativos a saúde humana e ao meio ambiente. Uma alternativa para o manejo é a utilização das plantas de cobertura. Esse trabalho teve como objetivo, determinar a composição florística das plantas daninhas em um agrossistema amazônico, com plantas de cobertura e avaliar a produção de biomassa, taxa de cobertura do solo e o potencial de supressão das plantas de cobertura sobre as plantas daninhas. $O$ delineamento experimental foi em blocos casualizados, em esquema fatorial $4 \times 2$. Os fatores em estudo foram as espécies de cobertura (Brachiaria ruziziensis, Canavalia ensiformis, Mucuna deeringiana) mais a testemunha que consistiu em espécies daninhas, avaliados em dois anos agrícolas (2017 e 2018), com quatro repetições. Digitaria horizontalis foi a espécie infestante mais importante, tendo sido totalmente suprimida por $B$. ruziziensis. Esta espécie de cobertura apresentou grande produção de biomassa, maior cobertura do solo e alta supressão das daninhas em agrossistema amazônico.

Palavras-chave: competição; controle; resíduos vegetais 


\section{Introduction}

Weed infestation is considered as one of the main interfering factors in the productive potential of crops, as they occur in cultivated areas in an undesirable or harmful way, competing with crops for water, light, nutrients and can also host insects, pathogens and nematodes, which in turn causes considerable losses to the cultivation (Zimdahl, 2018). Herbicides are the basis of weed control in agricultural production commercial systems; however, chemical control practice is questionable due to its possible negative impacts on food security, non-targeted organisms, beneficial species, public health, and the environment (Kropff \& Walter, 2000; Chauhan \& Gill, 2014).

There is also ample evolution of the resistance to herbicides in weed populations, resulting from their continued exposure to heavy doses of these chemical products (Booth et al., 2003; Kumar et al., 2020). Therefore, minimizing or completely avoiding altogether the use of synthetic herbicides has gained interest in researches concerning the weed management (Ulla et al., 2014).

To that end, using cover plants associated with commercial cultivations is an option for the sustainable weed management, an alternative to herbicides, since besides the suppressive effect on weeds, cover plants also promote improvement in soil quality, ensuring a good yield in the long term (Teasdale et al., 2007).

In Amazonian agrosystems, the diversity of weed species in agricultural cultivations is high and may present different forms of propagation and dispersion (Albertino et al., 2004; Miléo et al., 2016). Pinpointing the infestation community in the crop is the first step in adopting the management. Nonetheless, knowing the floristic composition of the area is not enough, being also necessary studying important parameters as well, such as frequency, density and abundance of these species within the community, in order to make decisions about the practices to be integrated in the management (Oliveira \& Freitas, 2008).

Cover plants have received significant research attention, as they are an alternative for controlling weeds, by shading the soil by inhibiting the germination of seeds from species that infest the crops and may end up competing with them. Cover plants also reduces the number of weeding and herbicide applications, thus decreasing the production costs as well, especially during the crop initial phase, in addition to providing organic matter to the soil and lessening erosion problems (Albuquerque et al., 2013).

Among the desirable characteristics of cover plants are the rapid initial establishment and their efficiency in covering the soil. Hence, the quantification of these parameters are of great importance for researches studying the weeds suppression potential, with cover plants (Lima et al., 2015).

With this in mind, the objective was to determine the floristic composition of weeds in an agricultural cultivation area associated with cover crops, as well as to evaluate the production of biomass, the rate of soil cover and the potential for suppression of cover crops on the weeds.

\section{Materials and Methods}

The experiment was conducted in a commercial plantation property of the company Agropecuária Jayoro Company, in the municipality of Presidente Figueiredo - Amazonas, located at the following geographical coordinates: Latitude: $01^{\circ} 96^{\prime} 04^{\prime \prime}$ $S$ and Longitude: $60^{\circ} 14^{\prime} 37^{\prime \prime} \mathrm{W}$, during the agricultural years of 2017 and 2018. The studied area had been cultivated with guarana for about 10 years and weed control was performed with the glyphosate herbicide due to the great diversity of species and the broad spectrum of the product. It was applied annually, from three to four times, with doses ranging from 720 to $1,080 \mathrm{~g}$ a.i. ha ${ }^{-1}$ of glyphosate, which corresponds to about 2 to $3 \mathrm{~L} \mathrm{ha}^{-1}$ of the commercial product.

The soil was classified as a yellow dystrophic "latossolo" (Oxisol), with the average annual rainfall precipitation during the study period of $2,500 \mathrm{~mm}$, mean temperature of $35 \stackrel{\circ}{\circ} \mathrm{C}$ and altitude of $122 \mathrm{~m}$.

The experimental design was in randomized blocks, in a $4 \times 2$ factorial design. The factors under study were three cover species (Brachiaria ruziziensis, Canavalia ensiformis and Mucuna deeringiana) plus one control group with weeds (absence of cover plants) evaluated during two agricultural years (2017 and 2018), with four replicates. The experiment area totaled $12,000 \mathrm{~m}^{2}$ of guarana cultivation.

After establishing the blocks and prior to sowing the cover plants, the floristic and phytosociological composition of the weeds were surveyed by using the random squares method, with the dimension of $0.50 \times 0.50 \mathrm{~m}$, set twice per plot, in the cultivation rows of the cover species.

The weeds were transported in plastic bags identified in line with the treatments where they were collected, for later identification according to family, genus and species, counting of individuals by species and dry matter weight. After obtaining the density and dry matter data, we calculated the relatives density, frequency and abundance, and the importance value index with formulas proposed by Mueller-Dombois and Ellenberg (1974), where: Absolute Frequency (Fre) = number of plots containing the species/total number of plots; Absolute Density (Den) $=$ total number of individuals per species/total area collected; Absolute Abundance $(\mathrm{Abu})=$ total number of individuals per species/total number of plots containing the species; Relative Frequency (Frr) = species frequency $\times 100 /$ total frequency of all species; Relative Density (Der) = species density $\times 100 /$ total density of all species; Relative Abundance $($ Abr $)=$ species abundance $\times 100 /$ total abundance of all species and the Importance Value Index (IVI) $=\mathrm{Frr}+$ Der + Abr.

These parameters were once again calculated at the end of the cover plant cycle, during the two agricultural years, once in January 2018 (agricultural year of 2017) and in December 2018 (agricultural year of 2018). After analyzing all phytosociological parameters, the Shannon species diversity index $-(\mathrm{H})$ was calculated using the formula $\mathrm{H}=-\sum \mathrm{Pi}^{*} \log \mathrm{Pi}$, in which $\mathrm{Pi}$ is the importance probability of each species, given by the formula $\mathrm{Pi}=\mathrm{ni}^{*} \mathrm{~N}-1$, with $\mathrm{ni}$ as the importance value of each species and $\mathrm{N}$ as the total importance value. 
For the similarity evaluation (estimate of the similarity degree in species composition) among botanical populations, the Sorensen Similarity Index (IS), IS = $(2 \mathrm{a} / \mathrm{b}+\mathrm{c}) \times 100$, in which $a=$ number of species common to both areas; while $b$ and $c=$ total number of species in the two compared areas. The IS ranges from 0 to 1 , deemed as maximum when all species are common to the areas and as minimum when there are no species in common.

The area was prepared with light harrowing and correction of the acidity as according to the soil analysis results, having been applied 3.35 ton ha-1 of dolomitic limestone (PRNT 91\%) and a phosphate fertilization with simple superphosphate $\left(20 \% \mathrm{P}_{2} \mathrm{O}_{5}\right)$ to meet the recommendations for cover plants.

The species used as cover plants were sown at the following densities: Brachiaria ruziziensis $-9 \mathrm{~kg} \mathrm{ha}^{-1}$; Canavalia ensiformis $-135 \mathrm{~kg} \mathrm{ha}^{-1}$; and Mucuna deeringiana $-80 \mathrm{~kg} \mathrm{ha}^{-1}$. The species $B$. ruziziensis was sowed on the rows and in between the plots, while $C$. ensiformis and $M$. deeringiana were sown at a depth of $2 \mathrm{~cm}$, with seeds spaced $10 \mathrm{~cm}$ apart, in two rows with a spacing of $0.50 \mathrm{~m}$ between them.

The evaluations of the soil cover percentage were during the flowering period of the cover species, by using the linear transection method. For this, we used a rope with 100 intervals spaced $0.10 \mathrm{~m}$ apart, adding up to $10 \mathrm{~m}$ in length. This rope was randomly extended on the diagonal of each plot, at two points, counting the intervals that had cover or weed plants, by means of visual analysis, in order to obtain the soil cover percentage.

At 90 days after sowing, period considered as the average for the flowering of cover species, biomass samples were randomly taken in each plot, from the shoot of both the cover plants and weeds in the control treatment, using a sampler with $0.12 \mathrm{~m}^{2}$ of area, totaling $0.24 \mathrm{~m}^{2}$ of sampled area per plot, in all treatments. Afterwards, these samples were dried in an oven with forced air circulation, at $65 \stackrel{\circ}{ } \mathrm{C}$, until reaching constant weight. Subsequently, the material was weighed in order to estimate the dry matter, which was then extrapolated to $1 \mathrm{ha}$, having the results been presented in $\mathrm{kg} \mathrm{ha}^{-1}$.

The biomass data from cover plants and weeds were subjected to the analysis of variance and their means compared by the Tukey test at $5 \%$ of significance.

\section{Results and Discussion}

During the first phytosociological survey in the whole area, prior to setting the experiment up, 3,304 individuals were registered, distributed over 22 weed species from 10 botanical families. Poaceae was the most representative family, having six species present and followed by Asteraceae with four species (Table 1).

In relation to class, a predominance of dicotyledons occurred, with $63.64 \%$ of the total identified plants, comprising 14 species and represented by eight families, while two families and eight species represented the monocotyledons (36.36\%). These results agree with other researches in the Amazonian agrosystem, where a greater numbers of species belonging to dicotyledons have also been recorded (Albertino et al., 2004; Miléo et al., 2016). Even though the monocotyledons represent a lower percentage of species in the composition of the weed community, their individuals number was higher (Table 1).

Table 1. Phytosociological parameters of weeds from an Amazonian agrosystem, arranged by botanical family, before implanting soil cover species. Presidente Figueiredo-AM, 2017.

\begin{tabular}{|c|c|c|c|c|c|c|c|}
\hline Species & Family & Class & No. tot. ind & Rel freq & Rel dens & Rel abund & IVI \\
\hline Alternanthera tenella & Amarantaceae & $\mathrm{D}$ & 4 & 1.9 & 0.12 & 0.49 & 2.51 \\
\hline Acanthospermum australe & Asteraceae & D & 49 & 6.66 & 1.48 & 1.7 & 9.85 \\
\hline Ageratum conyzoides & Asteraceae & D & 3 & 0.95 & 0.09 & 0.73 & 1.77 \\
\hline Conyza canadenses & Asteraceae & D & 27 & 1.9 & 0.82 & 3.29 & 6.01 \\
\hline Emilia sonchifolia & Asteraceae & D & 30 & 2.86 & 0.91 & 2.43 & 6.2 \\
\hline Praxelis pauciflora & Asteraceae & D & 108 & 3.81 & 3.27 & 6.57 & 13.6 \\
\hline Cleome affinis & Capparaceae & D & 10 & 0.95 & 0.3 & 2.43 & 3.69 \\
\hline Commelina benghalensis & Commelinaceae & $\mathrm{D}$ & 3 & 0.95 & 0.09 & 0.73 & 1.77 \\
\hline Cyperus iria & Cyperaceae & M & 5 & 0.95 & 0.15 & 1.22 & 2.32 \\
\hline Cyperus rotundus & Cyperaceae & $M$ & 101 & 2.86 & 3.06 & 8.19 & 14.1 \\
\hline Croton lobatos & Euphorbiaceae & $\mathrm{D}$ & 3 & 0.95 & 0.09 & 0.73 & 1.77 \\
\hline Euphorbia heterophylla & Euphorbiaceae & $\mathrm{D}$ & 55 & 3.81 & 1.66 & 3.35 & 8.82 \\
\hline Axonopus fissifolius & Poaceae & M & 1102 & 15.23 & 33.35 & 16.76 & 65.3 \\
\hline Brachiaria plantaginea & Poaceae & M & 25 & 0.95 & 0.76 & 6.08 & 7.79 \\
\hline Digitaria horizontalis & Poaceae & M & 249 & 10.47 & 7.54 & 5.51 & 23.5 \\
\hline Paspalum mandiocanum & Poaceae & $M$ & 104 & 5.71 & 3.15 & 4.22 & 13 \\
\hline Paspalum multicaule & Poaceae & M & 44 & 2.86 & 1.33 & 3.57 & 7.76 \\
\hline Paspalum paniculatum & Poaceae & $M$ & 548 & 15.23 & 16.59 & 8.34 & 40.1 \\
\hline Spermacoce latifolia & Rubiaceae & $\mathrm{D}$ & 778 & 17.13 & 23.55 & 10.52 & 51.2 \\
\hline Spermacoce verticillata & Rubiaceae & D & 50 & 0.95 & 1.51 & 12.17 & 14.6 \\
\hline Solanum paniculatum & Solanaceae & D & 2 & 0.95 & 0.06 & 0.49 & 1.5 \\
\hline Turnera ulmifolia & Turneraceae & D & 4 & 1.9 & 0.12 & 0.49 & 2.51 \\
\hline Total & & & 3034 & 99.93 & 100 & 100.01 & - \\
\hline
\end{tabular}

$\mathrm{M}=$ monocotyledons; $\mathrm{D}=$ dicotyledons; no. tot. ind = number of total individuals; rel freq = relative frequency; rel dens = relative density; rel abund = relative abundance; IVI = Importance value index. 
Weeds from Poaceae and Asteraceae families had the highest number of species, both having also been reported already as the most found in the guarana plantations of Amazonas (Albertino et al., 2004). Similar indexes were also found in sunflower-cultivated areas (Adegas et al., 2010), unveiling their high occurrence in various agricultural crops as weeds.

The Poaceae family is considered as quite representative in terms of weed species, known to produce large seed amounts, hence facilitating their dissemination. They also have the $\mathrm{C4}$ carbon-fixation cycle, bestowing high photosynthetic rates to this family when they are under high temperatures and light conditions (Ferreira et al., 2014). These circumstances are consistent with those recorded during the experiment, in Presidente Figueiredo - AM, where the average annual temperature was of $340 \mathrm{C}$.

Weed resistance to herbicides is strongly represented in the Amaranthaceae, Brassicaceae and Poaceae families, in relation to all weed species, and it is an agronomic problem that threatens food security as it compromises the herbicide effectiveness, hinders weed management and increases the production costs (Holt et al., 2013).

Overall, the Poaceae has fast growth, large mass accumulation and high photosynthetic efficiency. However, a study on its seed germination conditions verified that tropical species from the Poaceae family do not receive the necessary stimuli for the germination process when they are under straw (Carvalho et al., 2005).

Therefore, incorporating the technology of using cover plants as an integrated weed management may reduce the Poaceae species situtation, in addition to reducing herbicide application, thus preventing the emergence of resistant biotypes (Christoffoleti \& Carvalho, 2009).

While Poaceae species, in general, possess high coverage rates, Asteraceae species generally grow in lesser density, yet are rapidly spread by wind, facilitating their growth in open areas. This strategy of disseminating propagules mainly favors its characteristic of an aggressive colonization, hence resulting in the growth inhibition of other species (GromboneGuarantini \& Rodrigues, 2002).

Values attributed to the density, frequency and abundance of weed species are effective tools in a phytosociological evaluation, since they generate the importance value index (IVI) of each species within the agricultural ecosystem (Silva et al., 2018).

In relation to the species, the highest IVI was obtained by the Axonopus fissifolius (65.34), mainly due to the high values of its density (Table 1). A. fissifolius is a species considered as cespitosa and may have stolons, with stems ranging from 15 to $120 \mathrm{~cm}$ in height, classified as simple, or sometimes, branchy when close to the base (Smith et al., 1982). The genus Axonopus comprises plants that are generally perennial, rarely annual, stoloniferous or rhizomatous and of a creeping nature (Giraldo-Cañas, 2012).

Spermacoce latifolia was the second most important species, with an IVI equal to 51.20. Popularly known as "erva-quente" (or winged false buttonweed outside Brazil), it is an annual, herbaceous, prostrate or ascending plant, with reproduction by small and light seeds, produced in abundance and that infest mainly annual crops, coffee plantations, orchards and vacant lots. It demonstrates a better development in acidic soils, tolerating the shading (Ramires et al., 2011).

The genera Axonopus and Spermacoce have similar characteristics, often found in compacted and heavily used soils. Also known for their herbicide resistance, which can cause an increase in plant density, hindering the control of their infestations by the chemical method (Gallon et al., 2018).

At the end of the first year of the experiment, the treatments with cover plants provided a new floristic composition in the weed community, with the appearance of new species and the disappearance of others, compared to the first survey in the area (Table 2).

The control treatment had the highest species richness (8), followed by $M$. deeringiana (5) and $C$. ensiformis (4). No weeds were registered in the treatment with $B$. ruziziensis (Table 2). Cover plants reduced the weed diversity compared to the control treatment without cover, with relevance to $B$. ruziziensis, which suppressed all weeds.

Most of the species found in the control treatment persisted in the area, also found in the cover treatments, but with variation in their frequencies and densities. Poaceae was the family with the highest number of common species among all the treatments, with emphasis on the genus Digitaria, with two species in all treatments except for the $B$. ruziziensis cover (Table 2).

The most important species were Digitaria ciliaris and Digitaria horizontalis, which made their infestation potential evident. The genus Digitaria has competitive weed species that are aggressive and difficult to manage, infesting many agricultural crops such as cowpea, sweet sorghum, cotton, banana and sugarcane (Oliveira \& Freitas, 2008; Giancotti et al., 2017). They are perennial, erect grasses, which have striated stems and long internodes that ensures their dominance in the area.

The high seed production and pilosity nature of Digitaria, as well as their high germinative power, facilitate their dispersion over long distances by the wind, during practically all year. They reproduce both by seeds and by rhizomes, forming large clumps in the infested areas (Mondo et al., 2010).

During the first phytosociological survey, this genus was already in the area; however, after setting the covers up, they became more frequent. This may have been caused by the management practices held in the soil to implant the covers, favoring their dispersion and propagation. These species do not excel in poor soils, although they are quite aggressive in fertile soils. In this study, they were the first weeds to appear after operations of soil preparation, acidity correction and phosphate fertilization, which may have influenced in their appearance. All of these factors favor the development, propagation and consequently infestation of Digitaria species (Silva et al., 2009). 
Table 2. Phytosociological parameters of weeds from an Amazonian agrosystem, arranged by botanical family, after implanting soil cover species. Presidente Figueiredo-AM, 2017.

\begin{tabular}{|c|c|c|c|c|c|c|c|}
\hline Treatment & Infesting species & Family & No. tot. ind & Rel freq & Rel dens & Rel abund & IVI \\
\hline \multirow{7}{*}{ Control } & Emilia sonchifolia & Asteraceae & 28 & 3.39 & 2.39 & 0.05 & 5.84 \\
\hline & Praxelis clematidea & Asteraceae & 4 & 3.39 & 0.34 & 0.01 & 3.74 \\
\hline & Chamaesyce hirta & Euphorbiaceae & 7 & 3.39 & 0.6 & 0.01 & 4 \\
\hline & Paspalum dilatatum & Poaceae & 87 & 3.39 & 7.44 & 0.17 & 10.99 \\
\hline & Brachiaria plantaginea & Poaceae & 37 & 1.69 & 3.16 & 0.14 & 5 \\
\hline & Digitaria ciliaris & Poaceae & 5 & 1.69 & 0.43 & 0.02 & 2.75 \\
\hline & Total & & 367 & 32.19 & 31.37 & 0.62 & - \\
\hline \multirow{5}{*}{ Canavalia ensiformis } & Emilia sonchifolia & Asteraceae & 3 & 3.39 & 0.26 & 0.01 & 3.65 \\
\hline & Digitaria horizontalis & Poaceae & 245 & 5.08 & 10.94 & 0.31 & 16.34 \\
\hline & Digitaria ciliaris & Poaceae & 95 & 5.08 & 8.12 & 0.12 & 20.38 \\
\hline & Paspalum dilatatum & Poaceae & 33 & 3.39 & 2.82 & 0.06 & 6.27 \\
\hline & Total & & 376 & 16.94 & 22.14 & 0.5 & - \\
\hline \multirow{3}{*}{ Mucuna deeringiana } & Digitaria ciliares & Poaceae & 72 & 3.39 & 6.15 & 0.14 & 17.56 \\
\hline & Digitaria horizontalis & Poaceae & 21 & 3.39 & 1.79 & 0.04 & 5.22 \\
\hline & Total & & 150 & 15.24 & 12.81 & 0.29 & - \\
\hline Brachiaria ruziziensis & - & & - & - & - & - & - \\
\hline
\end{tabular}

${ }^{*}$ no. tot. ind = number of total individuals; rel freq = relative frequency; rel dens = relative density; rel abund = relative abundance; $I \mathrm{VI}=\mathrm{Importance}$ value index.

Other studies about weed suppression by cover plants also identified the genus Digitaria in all evaluated treatments, with $D$. horizontalis as the species with the highest occurrence. These studies registered a high importance value index and their appearance in the initial establishment period of the cover plants (Silva et al., 2009; Lima et al., 2014).

In the second year, the control treatment without cover plants had greater weed diversity, with $D$. horizontalis registering greater frequency, density and abundance, thus being the most important species, with an IVI of 38.02 (Table 3).

As for the treatment with jack bean, $D$. horizontalis was the most important weed species, while in areas covered with M. deeringiana, the species Zehneria indica, not registered in previous surveys, emerged with the highest IVI (Table 3).
Legumes reduced the weed numbers from the first phytosociological survey compared to the last, with three weeds found in each treatment (Table 3).

Species with high IVI were not always considered of difficult controling, as is the case of $D$. horizontalis, which had low frequency in all treatments when compared to the control group. Its persistence may be due to a large seed bank formed in the soil during the years the area was under conventional weed controlling.

Thereby, there is a transition profile of the weed community in the area, with most competing species typical of fallow areas, but also having some species specific to disturbed areas, such as those with intensive soil cultivation. Furthermore, as the weed density increases in a given location, interspecific

Table 3. Phytosociological parameters of weeds from an Amazonian agrosystem, ordered by botanical family, during the second year of implating soil cover species. Presidente Figueiredo-AM. Presidente Figueiredo-AM, 2018.

\begin{tabular}{cllccccc}
\hline Treatment & \multicolumn{1}{c}{ Infesting species } & Family & No. tot. ind & Rel freq & Rel dens & Rel abund & IVI \\
\hline \multirow{5}{*}{ Control } & Praxelis pauciflora & Asteraceae & 2 & 6.05 & 0.84 & 0.63 & 7.52 \\
& Phyllanthus niruri & Phyllanthaceae & 2 & 6.05 & 0.84 & 0.63 & 7.52 \\
& Digitaria horizontalis & Poaceae & 46 & 9.1 & 19.25 & 9.69 & 38.04 \\
& Paspalum multicaule & Poaceae & 16 & 3.03 & 6.69 & 10.12 & 19.84 \\
& Spermacoce verticillata & Rubiaceae & 31 & 9.08 & 12.97 & 6.53 & 28.58 \\
& Total & & 97 & 33.31 & 40.59 & 27.6 & - \\
\hline \multirow{5}{*}{ Canavalia ensiformis } & Ipomoea grandifolia & Convolvulaceae & 1 & 3.03 & 0.42 & 0.63 & 4.08 \\
& Euphorbia heterophylla & Euphorbiaceae & 1 & 3.03 & 0.42 & 0.63 & 4.08 \\
& Digitaria horizontalis & Poaceae & 51 & 3.03 & 21.34 & 32.24 & 56.61 \\
& Total & & 53 & 9.09 & 22.18 & 33.5 \\
\hline \multirow{5}{*}{ Mucuna deeringiana } & Emilia sonchifolia & Asteraceae & 2 & 3.03 & 0.84 & 1.26 & 5.13 \\
& Ipomoea grandifolia & Convolvulaceae & 1 & 3.03 & 0.42 & 0.63 & 4.08 \\
& Zehneria indica & Cucurbitaceae & 5 & 3.03 & 2.09 & 3.16 & 8.28 \\
& Total & & 8 & 9.09 & 3.35 & 5.05 \\
\hline
\end{tabular}

Brachiaria ruziziensis

* no. tot. ind = number of total individuals; rel freq = relative frequency; rel dens = relative density; rel abund = relative abundance; IVI = Importance value index. 
and intraspecific competition also intensifies, in a way so that weeds with taller heights and more developed become the most dominant, while the smaller ones are suppressed or die (Silva et al., 2018).

During the first year, cover plants reduced the weed number by $83 \%$ compared to the initial survey (Tables 1 and 2 ). While in the second year, it reached a $95 \%$ reduction in the number of these species in the guarana plantation, in comparison to the survey before setting the covers (Tables 1 and 3), which proves the suppressive effect of the cover plants used in this research.

Regarding the most representative families in the first survey (Table 1), Poaceae decreased by $77 \%$ in the first year (Table 2 ) and by $97 \%$ in the second year. For the Asteraceae family, the reduction was $93 \%$ in the first year (Table 2 ) and $99 \%$ in the second year.

The legumes $M$. deeringiana and $C$. ensiformis demonstrated a suppression potential because they had the lowest weed densities when compared with the control treatment (Tables 2 and 3).

The reduction in the number of species and weed density, in the treatment with $\mathrm{M}$. deeringiana, may have been caused by its low and aggressive growth habit, better distributing branches and leaves on the soil. This physical effect hinders the entrance of light photons into the weeds, impairing their growth due to the energy limitation for activating photosystems and competition for nutrients (Sage \& Kubien, 2003).

M. deeringiana shows a rapid initial growth, high biomass production and soil cover capacity, thus promoting a greater weed suppression. In a study with this species as green manure, $100 \%$ of soil coverage was attained due to its aggressive behavior; moreover, the senescence of its plant residues can cause allelopathic effects, preventing weed emergence (Monquero et al., 2009).

Although not evaluated in this research, the weed suppression observed in the treatment with $M$. deeringiana may have been caused by the release of allelochemicals. Several studies pointed out the allelopathic power of legumes such as $M$. deeringiana and $C$. ensiformis on other plants (Pereira et al., 2018; Vargas et al., 2018).

However, in C. ensifomis, probably this allelochemicals release was not able to inhibit or suppress the $D$. horizontalis species (Table 3). According to Monquero et al. (2009), allelopathic activity depends entirely on the way the mulch behaves on weeds, in relation to the quality, quantity, soil type, local microbial population, climatic conditions and how these weeds are present in the place.

C. ensiformis had a slow initial growth, leaving the soil exposed, thus favoring the germination of the seed bank present in the soil by the light incidence. In this case, the cover plant come to have a low competition degree with weeds, allowing their development in the area. However, after establishment, $C$. ensiformis plants started to occupy the soil entirely, promoting the adequate weed suppression.
The species $B$. ruziziensis completely suppressed weeds during the two years of its use as cover in the guarana plantation (Tables 2 and 3). Other researches with this cover type has similar results, where there was a $100 \%$ suppression of the weed occurrences (Lima et al., 2014).

This suppression capacity of $B$. ruziziensis may be due to its high capacity of biomass production throughout the year, forming a thick layer of plant material on the soil, preventing the light incidence for seed germination, also acting as a barrier for the emergence of seedlings that may germinate. This condition results in weed suppression (Lima et al., 2014; Forte et al., 2018).

Weeds found in areas with and without vegetation cover during the two years of evaluation (2017 and 2018) had a diversity index $(\mathrm{H})$ that ranged from a minimum of 0.46 , observed in the Canavalia ensiforms area with only 3 species in the year 2018, up to a maximum of 20.02 obtained in the control area in 2017 (Table 4). Overall, the most diverse communities were found in the control treatments during 2017 and 2018, where no weed management was associated.

This index demonstrates the potential of cover plants in suppressing weeds, presenting low species diversity in cover treatments.

The similarity coefficient can vary from 0 to 1 , deemed as maximum when all species are common and minimum when there are no species in common between the areas of each treatment and in relation to its evaluation year (Adegas et al., 2010).

Authors suggest that indexes above 0.50 indicate a high similarity between two compared areas (Felfili \& Venturoli, 2000). Hence, by considering 0.50 as the limit level, we can see that after two years (2017 and 2018) of applying treatments in the guarana planting, the areas have low weed species in common, since all the coefficients are below 0.50 (Table 5).

The main dissimilarity cause between treatments and evaluation periods can be explained by the different management conditions using cover plants in weed suppression, which influenced the decrease of their presence in the area, a potential already presented in this research.

Besides the characteristics of each used management, several authors state the similarity index is not only influenced by the characteristics inherent to the soil types and proximity between areas, but in relation to the edaphoclimatic

Table 4. Diversity index (Shannon - H) of weed communities from an Amazonian agrosystem, during the first and second year after implanting soil cover species. Presidente FigueiredoAM, 2018.

\begin{tabular}{lcc}
\hline \multicolumn{1}{c}{ Treatment } & Year & $\begin{array}{c}\text { Diversity Index } \\
\left(\mathbf{H}^{\prime}\right)\end{array}$ \\
\hline Controle & 2017 & 2.0253 \\
Canavalia ensiformis & 2017 & 1.1443 \\
Mucuna deeringiana & 2017 & 1.4879 \\
Controle & 2018 & 1.4295 \\
Canavalia ensiformis & 2018 & 0.4658 \\
Mucuna deeringiana & 2018 & 1.0532 \\
\hline
\end{tabular}


Table 5. Similarity coefficient of the phytosociological surveys of weeds from an Amazonian agrosystem, during two years, after implanting soil cover species. Presidente Figueiredo-AM, 2018.

\begin{tabular}{|c|c|c|c|c|c|c|}
\hline & CE I & CE II & MD I & MD II & Control I & Control II \\
\hline Canavalia ensiformis (2017) & $*$ & 0.16 & 0.40 & 0 & 0.42 & 0 \\
\hline Canavalia ensiformis (2018) & & $*$ & 0 & 0.28 & 0 & 0.46 \\
\hline Mucuna deenrigiana (2017) & & & $*$ & 0.16 & 0.25 & 0.18 \\
\hline
\end{tabular}

CE: Canavalia ensiformis, MD: Mucuna deenrigiana, I: 2017, II: 2018.

conditions of each season, which also influences germination, dispersion and weed development (Oliveira \& Freitas, 2008).

As for the dry weight of the covers, there was no significance for the year factor alone, nor for the interaction, yet it was significant for the covers. Concerning weed dry weight, the factors were significant in isolation and in interaction.

According to the joint analysis of the two years of study, in general, the production of dry weight from the covers was inversely proportional to the values recorded for weeds, i.e., in the treatments which the cover species had greater dry matter weights, weeds registered the smallest, and vice versa (Table 6). This fact is consistent with that verified for $B$. ruziziensis, which had the highest dry matter weights and, in the phytosociological survey, suppressed all weeds.

The high dry matter production of $B$. ruziziensis with total weed suppression is a desirable trait when choosing a cover plant.

High dry matter values of a cover species are related to the good formation of straw on the soil, which guarantees a reduction in the establishment of weeds, by means of factors such as the thermal amplitude, little light availability and formation of physical barrier (Monquero et al., 2009; Ferreira et al., 2018).

$M$. deeringiana and $C$. ensifomis, had the lowest DMC values and did not differ between themselves, consequently, the weeds from these two treatments had the highest DMW results, regardless of the agricultural year. Similar behavior between these two species was also observed in the phytosociological survey in the second year of the study, in which, areas covered with these two legumes presented an equal weed number, one of which is common to the both areas (Table 3).

Despite the lower dry matter accumulation of the legumes $M$. deeringiana and $C$. ensiformis, a suppressive effect on weeds took place due to their low dry matter production (Table 6). This result was consistent with the reduction in the values of all weed phytosociological parameters during the two agricultural years.

Table 6. Dry matter production ( $\mathrm{kg} \mathrm{ha}^{-1}$ ) of cover plants (DMC) and weeds (DMW) of an Amazonian agrosystem, during two agricultural years. Presidente Figueiredo-AM, 2017-2018.

\begin{tabular}{lcl}
\hline \multicolumn{1}{c}{ Cover plants } & DMC & DMW \\
\hline Brachiaria ruziziensis & $5.95 \mathrm{a}$ & $0.00 \mathrm{~b}$ \\
Canavalia ensiformis & $4.55 \mathrm{ab}$ & $0.43 \mathrm{a}$ \\
Mucuna deeringiana & $4.14 \mathrm{~b}$ & $0.71 \mathrm{a}$ \\
Coefficient of variation (\%) & 26.35 & 82.27 \\
\hline
\end{tabular}

*Means followed by the same letter in the column do not differ from each other by the Tukey test at $5 \%$ probability.
Dry matter production and weed suppression are also influenced by the cover plant cycle. Therefore, plants with shorter cycles are more efficient in suppressing weeds, when used as predecessors of the main crop, during a short period, as it happens in no-tillage practices. When this period extends, it facilitates the occurrence of weeds (Mhlanga et al., 2015).

Concerning the coverage rate, B. ruziziensis covered $100 \%$ of the soil, leading to total weed suppression (Figure $1 \mathrm{~A}$ and $\mathrm{B}$ ).

$C$. ensifomis and $M$. deeringiana provided soil coverage greater than $70 \%$, with a good weed suppression (Figure $1 \mathrm{~A}$ ). However, in the second year, $M$. deeringiana continued to show a good suppression, with $85 \%$ coverage, while $C$. ensiformis had a reduction in its coverage, with the rate of $64 \%$.

A study evaluating the coverage rate of $C$. ensiformis also found a reduction in the weed suppression, related to its erect

A. 2017

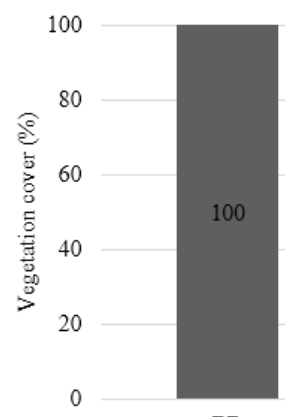

$\mathrm{BR}$

B.

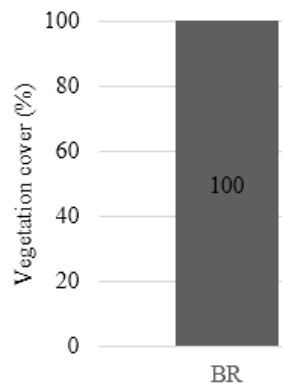

BR

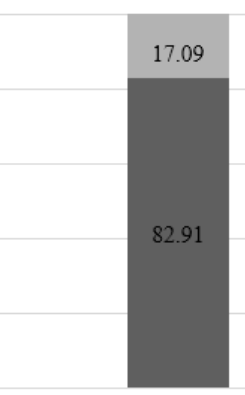

$\mathrm{CE}$

- Cover plants $\equiv$ Weeds

2018

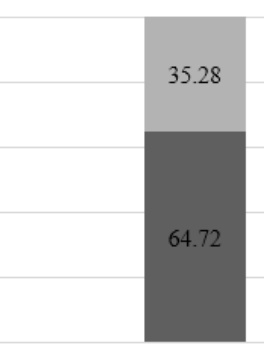

CE

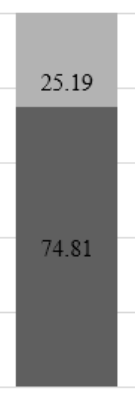

$\mathrm{MD}$

$$
\text { - Cover plants }=\text { Weeds }
$$

Figure 1. Percentage of vegetation cover over the soil provided by cover plants and weeds during the agricultural years of 2017 and 2018. BR - Brachiaria ruziziensis; CE - Canavalia ensiformis; MD - Mucuna deeringiana. Presidente FigueiredoAM, 2017- 2018. 
growth habit, which facilitates the light passage in between the rows. The solution to reduce this passage would be using a denser spacing in order to anticipate the total soil coverage and thus the weed suppression (Lima et al., 2014).

Altering the floristic composition of weeds during the development of cover plants emphasizes the importance of conducting phytosociological studies in different periods, in addition to the need of knowing the plant biology (Lima et al., 2014).

The dynamics of the species can vary in their floristic composition, depending on the type and intensity of cultural treatments imposed by the employed management types, which can change their populations and the distribution of species within the community (Silva et al., 2018).

Therefore, knowing the populations of weed species present in the area is of utmost importance in determining which is the best controlling method to be applied and, in the case of this study, it is also important evaluating the weed suppression potential of cover plants. The appearance of new species in the planting area may require changes in management strategies, and with that, determine new and different decisions taken by the farmer.

Thereby, we can state that weed suppression provided by cover plants is related to their growth rate and potential for total soil coverage. Hence, using covers can reduce weed occurrence or even suppress $100 \%$ of it when using the Brachiaria ruzizziensis as cover, with it deemed as suitable for using in guarana production.

\section{Conclusions}

Cover plants changed the floristic composition of the weed community in an Amazonian agrosystem, demonstrated by the reduction of species diversity, frequency, density and abundance of weeds. From an agronomic angle, the low weed diversity o suggests an easier, more efficient and less costly weed control.

Digitaria horizontalis was the most important weed species, suppressed only by Brachiaria ruziziensis. This cover type suppressed $100 \%$ of the weeds and had an excellent soil coverage, in addition to the higher biomass production among the evaluated coverage.

Using cover plants can bring great benefits for the integrated management of weeds, as they act in it mainly controlling herbicide-resistant species.

\section{Acknowledgements}

To the Coordination for the Improvement of Higher Education Personnel (CAPES) and the Research Support Foundation of Amazonas State (FAPEAM).

\section{Literature Cited}

Adegas, F.S.; Oliveira, M.F.; Vieira, O.V.; Prete, C.E.C.; Gazziero, D.L.P.; Voll, E. Levantamento fitossociológico de plantas daninhas na cultura do girassol. Planta Daninha, v.28, n. 4, p. 705-716, 2010. https://doi.org/10.1590/S0100-83582010000400002.
Albertino, S. M. F.; Silva, J. F.; Parente, R. C.; Souza, L. A. S. Composição florística das plantas daninhas na cultura de guaraná (Paullinia cupana), no Estado do Amazonas. Planta Daninha, v. 22, n. 3, p. 351-358, 2004. https://doi.org/10.1590/S010083582004000300004.

Albuquerque, A. W.; Santos, J. R.; Reis, L. S. Plantas de cobertura e adubação nitrogenada na produção de milho em sistema de plantio direto. Revista Brasileira de Engenharia Agrícola e Ambiental, v. 17, n. 7, p.721-726, 2013. https://doi.org/10.1590/ S1415-43662013000700005.

Booth, B.D; Murphy S.D; Swanton C.J. Weed ecology in natural and agricultural systems. 2.ed. Wallingford: CABI Publishing, 2003. 288p. https://doi.org/10.1079/9780851995281.0000.

Carvalho, S. J. P.; Nicolai, M.; López-ovejero, R. F.; Christoffoleti, P. J. Influência da luz, temperatura e profundidade da semente no solo sobre a germinação e emergência do capim-branco (Chloris polydactyla). Boletim Informativo-SBCPD, v. 12, n. 2, p. 11-15, 2005.

Chauhan B.S; Gill G.S. Ecologically based weed management strategies. In: Chauhan, B. S.; Mahajan, G. (Eds.). Recent Advances in Weed Management. New York: Springer, 2014. p.1-11. https:// doi.org/10.1007/978-1-4939-1019-9_1.

Christoffoleti, P. J.; Carvalho, S.J.P. Adaptadas, espécies infestantes resistem a herbicidas. Visão Agrícola, n. 9, p. 123-125, 2009. https://www.esalq.usp.br/visaoagricola/sites/default/files/VA9Protecao07.pdf. 29 Mar. 2020.

Felfili, J. M.; Venturoli, F. Tópicos em análise de vegetação. Comunicações Técnicas Florestais, v. 2, n. 2, p. 1-34, 2000.

Ferreira, A. C. D. B.; Borin, A. L. D. C.; Bogiani, J. C.; Lamas, F. M. Suppressive effects on weeds and dry matter yields of cover crops. Pesquisa Agropecuária Brasileira, v. 53, n. 5, p. 566-574, 2018. https://doi.org/10.1590/s0100-204×2018000500005.

Ferreira, E. A.; Fernandez, A. G.; Souza, C. P.; Felipe, M. A.; Santos, J. B.; Silva, D. V.; Guimarães, F. A. R. Levantamento fitossociológico de plantas daninhas em pastagens degradadas do Médio Vale do Rio Doce, Minas Gerais. Revista Ceres, v.61, n.4, p.502-510, 2014. https://doi.org/10.1590/0034-737X201461040008.

Forte, C. T.; Galon, L.; Beutler, A. N.; Basso, F. J. M.; Nonemacher, F.; Júnior, F. W. R.; Tironi, S. P. Sistemas de manejo do solo e sua influência no banco de sementes de plantas daninhas. Pesquisa Agropecuária Brasileira, v. 53, n. 4, p. 435-442, 2018. https://doi. org/10.1590/s0100-204×2018000400005.

Gallon, M.; Trezzi, M. M.; Diesel, F.; Possenti, J. C.; Batistel, S. C. Methods to promote Borreria latifolia seed germination. Revista Ciência Agronômica, v. 49, n. 3, p. 475-483, 2018. https://doi. org/10.5935/1806-6690.20180054.

Giancotti, P. R. F.; Moro, M. S.; Nepomuceno, M. P.; Barroso, A. A. M.; Martins, P. F. R. B.; Alves, P. L. C. A. Interferência e estudos fitossociológicos da comunidade infestante na cultura do sorgo sacarino. Planta Daninha, v.35, e017154150, 2017. https://doi. org/10.1590/S0100-83582017350100051.

Giraldo-Cañas, D. The species of the genus Axonopus (Poaceae: Panicoideae: Paspaleae) in Mexico. Caldasia, v. 34, n. 2, p. 325346, 2012. http://www.scielo.org.co/scielo.php?script=sci_ arttext\&pid=S0366-52322012000200006\&lng=en. 19 Mar. 2020. 
Grombone-Guaratini, M. T.; Rodrigues, R R. Seed bank and seed rain in a seasonal semi-deciduous forest in south-eastern Brazil. Journal of Tropical Ecology, v. 18, n. 5, p. 759-774, 2002. https://doi.org/10.1017/S0266467402002493.

Holt, J. S.; Welles, S. R.; Silvera, K.; Heap, I. M.; Heredia, S. M.; Martinez-Berdeja, A.; Ellstrand, N. C. (2013). Taxonomic and life history bias in herbicide resistant weeds: implications for deployment of resistant crops. PLOS ONE, v. 8, n. 9, p. e71916, 2013. https://doi.org/10.1371/journal.pone.0071916.

Kropff M.J; Walter H. EWRS and the challenges for weed research at the start of a new millennium. Weed Research, v.40, n.1, p.7-10, 2000. https://doi.org/10.1046/j.1365-3180.2000.00166.x.

Kumar, V; Obou, A; Jha, P; Liu R; Manuchehri M; Dille J; Stahlman $P$. Integrating cover crops for weed management in the semiarid U.S. Great Plains: opportunities and challenges. Weed Science, v.68, n.4, p.311-323. 2020. https://doi.org/10.1017/ wsc.2020.29.

Lima, L. B.; Petter, F. A.; Leandro, W. M. Desempenho de plantas de cobertura sob níveis de compactação em Latossolo Vermelho de Cerrado. Revista Brasileira de Engenharia Agrícola e Ambiental, v. 19 , n. 11 , p. 1064-1071, 2015. https://doi.org/10.1590/18071929/agriambi.v19n11p1064-1071.

Lima, S. F.; Timossi, P. C.; Almeida, D. P.; da Silva, U. R. Fitossociologia de plantas daninhas em convivência com plantas de cobertura. Revista Caatinga, v. 27, n. 2, p. 37-47, 2014. https:// periodicos.ufersa.edu.br/index.php/caatinga/article/view/3353. 29 Mar. 2020.

Mhlanga, B.; Cheesman, S.; Maasdorp, B.; Muoni, T.; Mabasa, S.; Mangosho, E.; Thierfelder, C. Weed community responses to rotations with cover crops in maize-based conservation agriculture systems of Zimbabwe. Crop Protection, v. 69, p. 1-8, 2015. https://doi.org/10.1016/j.cropro.2014.11.010.

Miléo, L.J.; Silva, J.F.; Albertino, S.M.F.; Leite, B.N.; Menezes, D.S.; Santos, A.F. Phytosociology of weeds in cultivation of two varieties of cassava1. Planta Daninha, v. 34, n. 2, p. 267-276, 2016. https://doi.org/10.1590/S0100-83582016340200008.

Mondo, V. H. V.; Carvalho, S. J. P.; Dias, A. C. R.; Marcos Filho, J. Efeitos da luz e temperatura na germinação de sementes de quatro espécies de plantas daninhas do gênero Digitaria. Revista Brasileira de Sementes, v. 32, n. 1, p. 131-137, 2010. https://doi. org/10.1590/S0101-31222010000100015.

Monquero, P.A.; Amaral, L.R.; Inácio, E.M.; Brunhara, J.P.; Binha, D.P.; Silva, P.V.; Silva, A.C. Efeito de adubos verdes na supressão de espécies de plantas daninhas. Planta Daninha, v. 27, n. 1, p. 8595, 2009. https://doi.org/10.1590/S0100-83582009000100012.

Mueller-Dombois, D.; Ellenberg, H. Aims and methods of vegetation ecology. New York: John Wiley, 1974. 547p.
Oliveira, A.R.; Freitas, S.P. Levantamento fitossociológico de plantas daninhas em áreas de produção de cana-de-açúcar. Planta Daninha, v. 26, n.1, p. 33-46, 2008. https://doi.org/10.1590/ S0100-83582008000100004.

Pereira, J. C.; Paulino, C. L. de Albuquerque; Granja, B. da S.; Santana, A. E. G.; Endres, L.; Souza, R. C. de. Potencial alelopático e identificação dos metabólitos secundários em extratos de Canavalia ensiformis L. Revista Ceres, v. 65, n. 3, p. 243-252, 2018. https://doi.org/10.1590/0034-737×201865030004.

Ramires, A. C.; Constantin J.; Oliveira Junior, R.S.; Guerra, N.; Alonso, D.G.; Raimondi, M.A. Glyphosate associated with other herbicides for control of Commelina benghalensis and Spermacoce latifolia. Semina: Ciências Agrárias, v. 32, n. 3, p.883-896, 2011. https:// doi.org/10.5433/1679-0359.2011v32n3p883.

Sage, R. F.; Kubien, D. S. Quo vadis C 4? An ecophysiological perspective on global change and the future of $C 4$ plants. Photosynthesis Research, v. 77, n. 2-3, p. 209-225, 2003. https://doi.org/10.1023/A:1025882003661.

Silva, A. C.; Hirata, E. K.; Monquero, P. A. Produção de palha e supressão de plantas daninhas por plantas de cobertura, no plantio direto do tomateiro. Pesquisa Agropecuária Brasileira, v. 44, n. 1, p. 22-28, 2009. https://doi.org/10.1590/S0100-204X2009000100004.

Silva, D. A.; Albuquerque, J. A. A.; Alves, J. M. A.; Rocha, P. R. R.; Medeiros, R. D.; Finoto, E. L.; Menezes, P. H. S. Caracterização de plantas daninhas em área rotacionada de milho e feijão-caupi em plantio direto. Scientia Agropecuaria, v. 9, n. 1, p. 7-15, 2018. https://doi.org/10.17268/sci.agropecu.2018.01.13.

Smith, L. B.; Wasshausen, D. C.; Klein, R. M. Gramíneas. Itajaí: Herbário Barbosa Rodrigues, 1982. 1407p. (Flora Ilustrada Catarinense, v.3).

Teasdale, J.R; Brandsæter, L.O; Calegari, A; Skora Neto, F. Cover crops and weed management. In: Upadhyaya, M.K.; Blackshaw, R.A. (Eds.). Non-chemical weed management, Vancouver: CAB International, 2007. Chap 4, p.49-64. https:/doi. org/10.1079/9781845932909.0049.

Ulla, M.E.D.; Kolseth, A.; Widmark, D.; Persson, P. Cover crop residues - effects on germination and early growth of annual weeds. Weed Science, v.62, n.2, p.294-302, 2014. https://doi.org/10.1614/wsd-13-00117.1.

Vargas, L.A.; Passos, A.M.A.; Karam, D. Allelopathic potential of Cover Crops in Control of Shrubby False Buttonweed (Spermacoce verticillata). Planta Daninha, v. 36, e018173359, 2018. https:// doi.org/10.1590/s0100-83582018360100052.

Zimdahl, R. L. Weed science: the future. In: Zimdahl, R. L. Fundamentals of weed science (Ed.). 5.ed. London: Academic Press, 2018. Chap. 23, p.651-681. https://doi.org/10.1016/b9780-12-811143-7.00023-8. 